\title{
Retraction Note To: Functional activation of Proline-rich Tyrosine Kinase2 (PYK2) in peripheral blood mononuclear cells from patients with systemic lupus erythematosus
}

Meiying Wang ${ }^{1 \dagger}$, Hongsheng Sun ${ }^{1 \dagger}$, Wei Zhang ${ }^{2}$ and Yuanchao Zhang ${ }^{1 *}$

\section{Retraction}

This article [1] has been retracted by the editors of BMC Musculoskeletal Disorders due to extensive overlap with previously published work [2]. We apologise for the inconvenience caused.

\footnotetext{
Author details

'Department of Rheumatology and Immunology, Provincial Hospital affiliated to Shandong University, Jinan 250021, China. ${ }^{2}$ Department of Pain Management, Hospital affiliated to Medical College of Qingdao University, Qingdao 266003, China.
}

Received: 7 January 2015 Accepted: 7 January 2015

Published online: 19 June 2015

\section{References}

1. Wang $M$, Sun $H$, Zhang $W$, Zhang Y. Functional activation of Proline-rich Tyrosine Kinase2 (PYK2) in peripheral blood mononuclear cells from patients with systemic lupus erythematosus. BMC Musculoskelet Disord. 2009;10:141.

2. Wang $M$, Zhang $W$, Zhang $Y$. Activation signal transduction by Proline-rich Tyrosine Kinase 2 (PYK2) in Peripheral blood mononuclear cells from patients with systemic lupus erythematosus. Hybridoma. 2009;28:5.

\footnotetext{
* Correspondence: sdfs2004@sohu.com

${ }^{\dagger}$ Equal contributors

'Department of Rheumatology and Immunology, Provincial Hospital affiliated to Shandong University, Jinan 250021, China

Full list of author information is available at the end of the article

Submit your next manuscript to BioMed Central and take full advantage of:

- Convenient online submission

- Thorough peer review

- No space constraints or color figure charges

- Immediate publication on acceptance

- Inclusion in PubMed, CAS, Scopus and Google Scholar

- Research which is freely available for redistribution

Submit your manuscript at www.biomedcentral.com/submit 